\title{
Article \\ Efficacy of different green manuring crops to soil fertility, yield and seed quality of T. aman rice
}

\author{
I.J. Irin ${ }^{1 *}$, P.K. Biswas ${ }^{2}$ and M.A. Khan ${ }^{3}$ \\ Dept. of Agronomy, Khulna Agricultural University, Bangladesh \\ Dept. of Agronomy, Sher-e-Bangla Agricultural University, Dhaka-1207, Bangladesh \\ Dept. of Soil Science, Sher-e-Bangla Agricultural University, Dhaka-1207, Bangladesh \\ *Corresponding author: I.J. Irin, Assistant Professor, Dept. of Agronomy, Khulna Agricultural University, \\ Bangladesh. E-mail: isratjahankau20@gmail.com
}

Received: 22 August 2021/Accepted: 23 October 2021/ Published: 30 December 2021

Copyright (C) 2021 I.J. Irin et al. This is an open access article distributed under the Creative Commons Attribution 4.0 International License (https://creativecommons.org/licenses/by/4.0/), which permits unrestricted use, distribution, and reproduction in any medium, provided the original work is properly cited.

\begin{abstract}
A series of experiments were conducted on the Agronomy farm and laboratory of Sher-e-Bangla Agricultural University to demonstrated a promising way of increasing soil organic matter, total $\mathrm{N}$ in pre sown and postharvest land by green manure cultivation and reducing the inorganic fertilizer inputs in rice production and finally observed the quality of grown T. aman seed in laboratory condition. Several green manures were found more potential in two years regarding their plant height, dry biomass production and better performance concerning organic matter, nitrogen and potassium contribution to soil and increased rice yield. Morphological characteristics of eight green manure crops were studied and incorporated at 45DAS for decomposition. One month after decomposition of green manure, rice (BRRI dhan66) plant was transplanted with $100 \%$ NPK $\left(F_{1}\right)$ and 50\% NPK $\left(\mathrm{F}_{2}\right)$ and pre sown rice soil, post-harvest soil nutrient statuses were studied. Result showed that Pre shown rice soil increased 0.5 to $0.6 \%$ SOM ( $2^{\text {nd }}$ year), $0.04 \%$ soil N (both year) and $0.04 \%$ soil K ( $1^{\text {st }}$ year) which ultimately increase rice yield $62 \%$ to $68 \%$ (with F1) and $10 \%$ to $42 \%$ in $1^{\text {st }}$ and $2^{\text {nd }}$ year. Post-harvest soil nutrient status shown the positive balance of $(0.1 \%$ to $1 \%)$ organic matter and total $\mathrm{N}(0.04 \%$ to $0.7 \%)$ in the $1^{\text {st }}$ years and $2^{\text {nd }}$ years and $\mathrm{P}$ was found drastically increased in $2^{\text {nd }}$ year, respectively. Germination\%, germination energy\%, seedling length, fresh and dry weight of six month stored rice seedling also found highest from $S$. rostata and $S$. aculeata under laboratory condition. Incorporation of Sesbania aculeata, S. rostrata, $V$. unguiculata and Crotalaria juncea as GM with $\mathrm{N}$ significantly influenced the grain yield of rice and pre and post-harvest soil.
\end{abstract}

Keywords: green manuring; soil fertility; dry matter; cotyledon length; radicle length; germination energy percentage, dry weight

\section{Introduction}

To meet up excessive food demand for increasing population, soil fertility in Bangladesh is declining day by day and the organic matter status of soil is below $1 \%$ in more than $60 \%$ of total cultivable lands whereas ideal level is 3\% (Islam, 2006). Inorganic fertilizers are very expensive to make the soil fertile even though green manure is a very low cost technology in reducing fertilizer costs and increasing soil fertility. Green manure crops are one of the most effective ways to improve the soil. Green manures belonging to the pea and bean family (legumes) have the additional capacity of storing (fixing) nitrogen from the air to their root nodules. Green manure is a glimmer of hope in that aspect as it has the ability to fix atmospheric nitrogen and improves soil fertility. Khind et al. (1983) spotted that, when 30, 45 and 60 days old crop with dhaincha (Sesbania aculeata) incorporated one 
day before transplanting of rice the amount of green matter, dry matter accumulation and nitrogen added increased progressively with the increase in age of dhaincha and the increase in the yield with the incorporation of 60 days old dhaincha was equivalent to yield from $120 \mathrm{~kg} \mathrm{~N}^{-1}$ through urea. Kumar (2010) opined that dhaincha helps to improve the physical and biochemical structure of the soil, prevent leaching losses of nutrients, enhancing water holding capacity, preventing weed growth, reducing residual effect of chemicals and also helps in reducing the soil borne inoculum of phytopathogens. Growing of green manure crops in the off season reduces weed proliferation and weed growth. Sarwar et al. (2017) reported that the increment of rice grain yield was $7 \%$ to $39 \%$ in dhaincha incorporated soil with the recommended doses of PKS fertilizers over the control (no green manure). Plant height, total number of tillers hill ${ }^{-1}$, effective tillers hill ${ }^{-1}$, primary branches panicle $^{-1}$, number of filled grains panicle ${ }^{-1}$, grain yield and straw yield significantly differed; however, panicle length did not differ after biomass incorporation of different dhaincha accessions. Noor et al. (2015) stated that rice grain yield increased $32 \%$ to $77 \%$ over the control due to (dhaincha) green manure incorporation with different doses of NPK fertilizers application. In Indian perspective, the yield of high yielding rice varieties was increased from 0.65 to $3.1 \mathrm{t} \mathrm{ha}^{-1}$ due to use of green manure (Singh et al., 1991). Pramanik et al. (2004) documented the best performance of Sesbania rostrata influencing plant height and total number of tillers hill ${ }^{-1}$ of rice and added that the application of various organic manures improved the plant growth of rice and wheat crops. According to Biswas et al. (1996), the inclusion of green manure crop in the soil has reduced 50 percent of the recommended $\mathrm{N}$ levels for subsequent rice. The introduction of green manure crops not only improves the nitrogen quality of the soil but also helps to reduce the cost of fertilizer. But the lack of financial benefits, the planting of green manure is ignored by many people. But, after harvesting Boro rice, the main field usually remains unploughed for about 2-3 months. This time can be used to grow green manure without sacrificing main crops. To improve soil and crop production, the integration of legume cover crops into planting systems has now been emphasized by tropical farmers (Odhiambo et al., 2010). For the above facts, the current experiments were conducted to identify suitable green manure crops and their ability to improve rice yield and soil fertility.

\section{Materials and Methods}

A group of experiments was conducted at the Agronomy farm of Sher-e-Bangla Agricultural University during April, 2015 to April, 2017 to evaluate the morphological performance of different green manuring crops and its residual effect on rice yield and post-harvest rice soil performances through adding biomass, dry matter, organic matter, N, K and P accumulation and finally stored T. aman seed performance in laboratory. The eight green manure crops viz. Desi dhaincha (Sesbania aculeata), African dhaincha (Sesbania rostrata), Sunn Hemp (Crotalaria juncea), Mungbean (Vigna radiata), Blackgram (Vigna mungo), Cowpea (Vigna unguiculata), Ipilipil (Leucaena leucocephala) and Mimosa (Mimosa pudica) were planted (experiment laid out in a randomized complete block design) from seed and different morphological data were taken at 45 DAS. After 45 DAS, all green manuring crops were incorporated to soil and thirty days after incorporation of green manuring crops, transplant aman (BRRI dhan64) were planted along with two nitrogen Fertilizer doses (100\% and 50\% NPK fertilizer doses from recommended fertilizer dose of rice). The initial and final soil sample of each experimental plot $(0-15 \mathrm{~cm})$ was collected for analyzing soil chemical properties. Two fertilizer doses and eight types of green manures were tested on rice (succeeding crop) in a split-plot design with three replications, where fertilizer doses (100\% and 50\% recommended doses of urea) was assigned in the main plots and green manure crops (previous crop field) in the sub-plot. The size of each plot was $17.50 \mathrm{~m}^{2}(5 \mathrm{~m} \times 3.5 \mathrm{~m}$ ). The experimental plots were fertilized with 20-17.6-24.9 $\mathrm{kg} \mathrm{N}, \mathrm{P}$ and $\mathrm{K} \mathrm{ha}^{-1}$ from their sources of Urea, TSP and MoP. Different yield contributing average data were taken from rice field. Analyzed statistically by using the Statistic-10 computer package. The mean comparisons of all parameters were done with Tukey's W- procedure (Gomez and Gomez, 1984).

\subsection{Species description}

Eight species viz. Sesbania aculeata, Sesbania rostrata, Crotalaria juncea, Vigna unguiculata, Vigna mungo, Vigna radiata, Leaucena leaucocephala, Mimosa pudica were selected as green manuring crop species. The leaves of these plants are easily decomposable and reported to contain more protein, and rich source of nitrogen and phosphorus when used as green manure. Total biomass was estimated each time before incorporation. At the age of 45 days, all green manuring plants were harvested, chopped into small pieces incorporated to the individual plot and allowed for decomposition for one month. 
2.2. Transplanting of rice seedling

Sprouted of BRRI dhan66 seeds were sown in the wet nursery bed on 13 June 2015 (for $1^{\text {st }}$ experiment) and 5 July 2016 (for $2^{\text {nd }}$ experiment). Proper care was taken to raise the seedlings in the nursery bed. The 30 days old seedlings were uprooted carefully without causing mechanical injury to the roots and were transplanted on 13 July 2015 (for $1^{\text {st }}$ experiment) and 5 August 2016 (for $2^{\text {nd }}$ experiment) in $54(3 \times 18)$ experimental plots those were puddled further with spade on the day of transplanting. Three seedlings were transplanted in each hill with $20 \mathrm{~cm}$ and $20 \mathrm{~cm}$ spacing between the rows and hills respectively.

\subsection{Soil sample collection \& soil chemical analysis}

Composite soil sample from each plot for the two years were collected in following sequences:

I. Pre-sowing

II. After decomposition of green manure $\left(1^{\text {st }}\right.$ year and $2^{\text {nd }}$ year $)$

III. Post harvest of Aman rice $\left(1^{\text {st }}\right.$ year and $2^{\text {nd }}$ year $)$ and

All collected samples were sun dried and sieved through a $2 \mathrm{~mm}$ sieve. The soil samples were analyzed for organic matter, total nitrogen, available phosphorus and exchangeable potassium following standard methods.

\section{Results and Discussion}

\subsection{Morphological characteristics of different green manuring crops}

There were significant differences observed in plant height among the green manure crops throughout the growth period in two years (Table 1). At 45 DAS ( $1^{\text {st }}$ year), S. rostrata showed $148 \%$ tallest plant height followed by S. aculeata (104\%), V. unguiculata (102\%) and L. leucocephala (86\%) compared to V. mungo. In $2^{\text {nd }}$ year, S. rostrata and S. aculeata showed $8 \%$ and $2.9 \%$ more plant height whereas C. juncea showed $20 \%$ more plant height compared to $1^{\text {st }}$ year. On the other hand $V$. mungo and $V$. radiata showed the shortest plant height in both years. Pramanik et al. (2009) also obtained the similar result, reporting higher plant height in Sesbania among evaluating different green manuring crops and stated that, $S$. rostrata gave the highest height followed by S. aculeata and C. juncea. Srivastava and Girjesh (2013) stated that the maximum plant height was observed with Sesbania spp. as $111.60 \mathrm{~cm}$ at the density level of 50 plants pot $^{-1}$ at 45 DAS.

It was observed that, S. rostrata, S. aculeata and $C$. juncea dry biomass yield increased rapidly apparently with the age of the plant compared to other green manuring crops. The highest dry biomass was given by Crotalaria juncea that (5.03 t/ha) followed by Sesbania rostrata and Sesbania aculeata. Singh (1981) also agreed with the findings and reported that the most productive green manure crops yielded about 4-5 tha ${ }^{-1}$ of dry biomass in 5060 days and cluster bean has generally been less productive than Sesbania, sunn hemp, and cowpea in descending order. Zaman et al. (1995) opined that in Bangladeshi condition, 60 days old dhaincha (S. aculeata) plants produced $5.2 \mathrm{t} \mathrm{ha}^{-1}$ dry matters which yielded $135 \mathrm{~kg} \mathrm{~N} / \mathrm{ha}$. There was significant variation on nodule production plant ${ }^{-1}$ observed among green manuring crops at 45 DAS (Table 1). S. rostrata and S. aculeata produced the highest nodule in both year and it was $42 \%$ and $53 \%$ higher from $1^{\text {st }}$ year whereas M. pudica along with $V$. unguiculata, $V$. mungo and $L$. leucocephala produced the lowest nodule in two years. The results was almost similar to the findings of Pramanik et al. (2009) who found the highest number of nodules plant ${ }^{-1}$ from $S$.

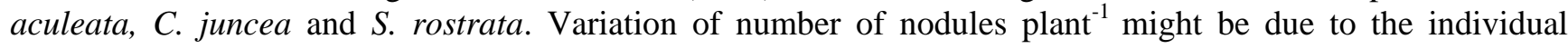
genetic characteristics of green manure crops.

\subsection{Effect of green manuring crops on chemical properties of previous and postharvest rice soil in two years}

\subsubsection{Soil organic matter}

Soil fertility status was monitored from 20151017 and found that incorporation of eight diferent green manuring crops (Pre-sown rice soil) increased soil organic matter from $1.01 \%$ (initial) to $1.08 \%$ in $1^{\text {st }}$ year (2015) and up to $1.61 \%$ in $2^{\text {nd }}$ year (2016) (Figure1). The $0.14 \%$ higher organic matter was found in $\mathrm{T}_{2}$ in 2015 and $0.4 \%$ to $0.6 \%$ was recorded from $\mathrm{T}_{1}, \mathrm{~T}_{2}$ and $\mathrm{T}_{5}$ in 2016.The cumulative effect of green manuring crops resulted more organic matter compared to previous year due to slow release of nutrients from decaying green manure crops and higher production of biomass from T1 and T2 crops leading to add more organic residues in soil. After harvesting rice, soil organic matter was found higher in $2^{\text {nd }}$ year compared to $1^{\text {st }}$ year (Table 3 ) and $S$. aculeata $\left(0.7 \%\right.$ in $\mathrm{F}_{1}$ and $0.4 \%$ in $\left.\mathrm{F}_{2}\right)$, S. rostratra $\left(0.8 \%\right.$ in $\mathrm{F}_{1}$ and $0.5 \%$ in $\left.\mathrm{F}_{2}\right)$, C. juncea $\left(0.6 \%\right.$ in $\mathrm{F}_{1}$ and $0.5 \%$ in $\mathrm{F}_{2}$ ) and L. leucocephala $\left(0.5 \%\right.$ in $\mathrm{F}_{1}$ and $0.5 \%$ in $\mathrm{F}_{2}$ ) showed the increased trend compared to control. Microbial activity from incorporation of green manuring crops into the soil leads to the formation of mycelium and viscous materials which benefit the health of the soil by increasing its soil structure, improves water infiltration 
and retention, aeration. Mann et al. (2000) reported that after continuous green manuring of three years, the soil organic matter increased up to $1.09 \%$. Ali et al. (2012) found that among green manures, Sesbania incorporated plot increased soil organic matter $(0.79 \%)$ from its initial soil (0.67). It indicated that Sesbania rostrata and S. aculeata is much more beneficial to soil health than any other green manures when incorporated along with reduction doses of chemical fertilizer in the $\mathrm{T}$. aman season.

\subsubsection{Total $\mathbf{N}$}

After green manure incorporation, total $\mathrm{N}$ status of soil ranged from $0.04 \%$ to $0.084 \%$ for the two years (initial level $0.04 \%$ ) (Figure 2) and the significantly highest amount of total $\mathrm{N}$ was observed in $\mathrm{T}_{2}$ followed by $\mathrm{T}_{6}$ and the lowest $(0.03 \%)$ obtained from $\mathrm{T}_{5}$. Post-harvest soil shown a drastically increased of total $\mathrm{N}$ in $2^{\text {nd }}$ year compared to $1^{\text {st }}$ year which was $0.10 \%$ to $0.11 \%$ (F1 and F2), where Sesbania species and C. juncea were incorporated into soil with 50\% chemical fertilizer (Table 3). These results suggested that green manuring of Sesbania would have increased $\mathrm{N}$ fertility of soil because of greatest $\mathrm{N}$ contents in their biomass and incorporation of green manure into the soil allows the nutrients held within the green manure to be released and made available to the succeeding crops and ultimately reduced fertilizer cost. Moreover, legume crops root system is rich in rhizobium which interacts with green manure to retain atmospheric nitrogen in the soil. Mann et al. (2000) reported that Sesbania incorporated plot increased soil N (0.60\%) from initial soil (0.48\%). Rahman et al. (2013) stated that total $\mathrm{N}$ status of soil ranged from 0.075 to $0.098 \%$ (initial level $0.078 \%$ ) after three years of continuous dhaincha biomass incorporation.

\subsubsection{Other nutrients ( $K$ and $P$ )}

Among other nutrients, $\mathrm{K}$ showed slightly increasing trends $(0.22 \mathrm{meq} / 100 \mathrm{~g})$ in $1^{\text {st }}$ year from initial soil $(0.18 \mathrm{meq} / 100 \mathrm{~g})$ and the highest $\mathrm{K}$ was obtained from $\mathrm{T}_{1}$ and $\mathrm{T}_{2}$ followed by $\mathrm{T}_{3}(0.21 \mathrm{meq} / 100 \mathrm{~g})$ and $\mathrm{T}_{4}(0.20$ $\mathrm{meq} / 100 \mathrm{~g}$ ) that was superior to initial soils (Table 2). In the second year, there was a declining trend shown in $\mathrm{K}$ status in soil compared to initial soil which was same in post-harvest soil (Table 4). Increased K availability after green manuring has been reported by Kute and Mann (1969) and Debnath and Hajra (1972). In contrast, Sahu and Nayak (1971) observed a slight decline of K after green manure. In case of P in soil, a declined trend in both years was found compared to initial soil $(15.83 \mathrm{ppm})$. After harvesting of rice, drastically increasing trend $(\mathrm{T} 2>\mathrm{T} 1>\mathrm{T} 3>\mathrm{T} 5>\mathrm{T} 4>\mathrm{T} 8>\mathrm{T} 6)$ was observed among all green manures with two doses of fertilizer in $2^{\text {nd }}$ year compared to $1^{\text {st }}$ year and $S$. aculeata $\left(7.8 \mathrm{ppm}\right.$ in $\mathrm{F}_{1}$ and $11.31 \mathrm{ppm}$ in $\left.\mathrm{F}_{2}\right)$, S. rostrata $\left(16 \mathrm{ppm}\right.$ in $\mathrm{F}_{1}$ and $11.14 \mathrm{ppm}$ in $\mathrm{F}_{2}$ ), and $C$. juncea (5 ppm in $\mathrm{F}_{1}$ and $10 \mathrm{ppm} \mathrm{F}_{2}$ in), showed the increased $\mathrm{P}$ content (Table 4). The above plant matter releases large amounts of carbon dioxide and weak acids that react with insoluble soil minerals to release beneficial nutrients. Soils that are high in calcium minerals, given green manure can generate a higher phosphate in the soil, which in turn acts as a fertilizer. The increase in available $\mathrm{P}$ concentration of soil may be due to greater mobilization of native soil $\mathrm{P}$ by vigorous root proliferation and contribution through biomass. The excess soil P would help farmers to reduce fertilizer cost. Georgantas and Grigoropoulou (2006) opined that, in $\mathrm{pH}$ values less than 6 create a chemical bond between aluminum (Al) and phosphate; whereas in higher values of soil $\mathrm{pH}$ (6-8), adsorption of phosphate ions occur on solid $\mathrm{Al}$ or Fe hydroxide. The $\mathrm{P}$ value decrease might be due to the low $\mathrm{pH}$ and $\mathrm{P}$ fixation in soil.

\subsection{Effect of green manuring crops and nitrogen levels on SPAD and Grain protein content of rice}

The SPAD (Soil Plant Analysis Development) value represents the greenness of leaf. SPAD is a tool for measuring leaf chlorophyll content by which plant $\mathrm{N}$ level can be indirectly estimated. The SPAD value was recorded from the upper two fully expanded leaves of the main tiller and the average value was recorded. Incorporation of Sesbania rostrata, $S$. aculeata and $V$. mungo, $V$. unguiculata, with $\mathrm{N}$ significantly increased the SPAD reading of rice. (Table 5).The maximum SPAD value was found from $\mathrm{T}_{2}(44.47)$ with $50 \% \mathrm{~N}$ fertilizer which was statistically similar to $V$. mungo (44.47) with $100 \%$ fertilizer. The chlorophyll content was increased with the progress of plant age, thereafter it declined regardless of treatments. However, the decreasing trend was slower in GM treated plants as it has the ability to fix atmospheric nitrogen and converts into plant-usable form. It has been reported that higher doses of nitrogen fertilizer showed significantly higher SPAD meter reading at different growth stages of rice (Gholizadeh et al., 2009). Green manure might be substitute of the $\mathrm{N}$ and other plant nutrients and helped in maintaining the higher chlorophyll content in rice. After 70 days of transplanting, the chlorophyll content was decreased regardless of treatments. This was probably because of the transferring of nutrient elements of the green leaves to the seeds. Chlorophyll meter values were closely related to grain protein content of rice (Table 5). The variation in grain protein content ranged from $7.70 \%$ to $8.41 \%$ and the highest grain protein $(8.54 \%)$ was in S. rostrata with $50 \% \mathrm{NPKha}^{-1}$ followed by $C$. juncea (8.235) however the value 
was statistically similar with other crops when subjected to different NPK levels. The lowest one was recorded in control (7.54\%) plot with 50\% $\mathrm{NPKha}^{-1}$. Safiqual et al. (2015) reported that the maximum nitrogen and protein content in grain was produced when green manuring crops were incorporated, and that amount was higher than fallow with higher dose of nitrogen.

\subsection{Effect of green manuring crops and nitrogen levels on 1000-grain weight and yield of rice}

The 1000- grain weight was significantly influenced by interaction effect between NPK levels and green manuring crops (Table 6). In both year, the highest grain weight $(23.94 \mathrm{~g}$ and $24.11 \mathrm{~g})$ was obtained from the treatment combination of the variety $S$. rostrata with $100 \% \mathrm{NPK} \mathrm{ha}^{-1}$ which was statistically similar to the same treatments under the 50\% NPK ha ${ }^{-1}$ levels $(23.87 \mathrm{~g}$ and $23.54 \mathrm{~g}$ in 2015 and 2016 respectively) and the lowest one ( $22.08 \mathrm{~g}$ and $21.36 \mathrm{~g}$ ) was obtained by the interaction of the control plot $100 \%$ NPK level. Many researchers also observed a significant and positive correlation between SPAD values and rice grain yield (Swain and Sandip, 2010). The combined effect of NPK levels and green manuring crops had a significant influence on grain yield (Table 6). The highest grain yield $\left(5.23 \mathrm{t} \mathrm{ha}^{-1}\right.$ and $\left.5.56 \mathrm{tha}^{-1}\right)$ was obtained from the treatment combination of the T2 followed by T1 $\left(5.13 \mathrm{t} \mathrm{ha}^{-1}\right.$ and $\left.5.3 \mathrm{tha}^{-1}\right)$ with $100 \%$ NPK fertilizer which was statistically similar to the combination of 50\% NPK fertilizer in 2015 and 2016 respectively and the lowest one ( $3.10 \mathrm{t} \mathrm{ha}^{-1}$ and $3.43 \mathrm{tha}^{-1}$ ) was obtained by the interaction of the control (absent of green manure) and with F1 and F2. The increased grain yield may be due to more availability of nitrogen and other nutrients to rice crop released by incorporation of same green manure in two consecutive years. The lowest amount $\left(3.42\right.$ tha $^{-1}$ and 3.70 tha $^{-1}$ ) of grain yield was obtained without green manure treated plot in 2015 and 2016 respectively. This result supported by Ehsan et al. (2014) who stated that, the rice grain yield increased 32\% to $77 \%$ over control due to green manure (dhaincha) incorporation with different doses of NPK fertilizers application. In addition to the macro-nutrients ( $\mathrm{N}, \mathrm{P}$, and $\mathrm{K}$ ), green manuring plants also contains micro-nutrients (e.g. $\mathrm{Ca}, \mathrm{Mg}, \mathrm{Si}$, and $\mathrm{Zn}$, etc.) (Chen and Zhao, 2009), which may promote and maintain the sustainable nutrients supply to the soil. Efthimiadou et al. (2010) found that combining GM with $\mathrm{N}$ enhanced the photosynthetic rate and stomatal conductance of rice, and led to increase in the dry matter accumulation as well as rice yield versus $\mathrm{N}$ fertilizers alone. These positive effects of GM may be the result of the aboveground and/or belowground plant biomass, with high amount of $\mathrm{N}$ and a relatively low carbon-to-nitrogen ratio $(\mathrm{C} / \mathrm{N})$, leading to release of plant-available $\mathrm{N}$ (Gilmour et al., 1998).

\subsection{Residual effect of different green manuring crops on stored rice seed germination \%, germination energy \%, radicle and cotyledon length, fresh weight and dry weight under laboratory condition}

The residual effect of green manuring crops on germination of stored rice seeds were not significant (Table 7). Seed vigor as expressed in terms of seedling length was significantly affected by different fertilizer treatments at 11DAG and 13 DAG (Table. 7). Cotyledon lengths were taken after two days interval from germination. The highest cotyledon length was found from V. unguiculata and S. rostrata followed by L. leucocephala whereas control showed the lowest performances at 11DAG and 13DAG (Days after germination).Again radicle length showed the significant difference at 11 DAG and Sesbania rostrata gave the highest result. Hossain (2014) stated that, maximum seedling length $(18.02 \mathrm{~cm})$ was found in seeds that produced without fertilizers $\left(\mathrm{T}_{1}\right)$ which was statistically similar to seed produced under recommended NPKSZn chemical fertilizer dose with green manure $5 \mathrm{t} / \mathrm{ha}\left(\mathrm{T}_{5}\right)$. The better filling of seeds indicates the better food reserves in the seeds treatments, might have resulted in better quality parameter (Krishna et al., 2008). In soil where nutrients are easily available, shoot growth can take more preference over roots. After the establishment phase, seedling growth rate is a function of soil nutrient status (Mishra and Salokhe, 2008). Primary stem length of seeds in laboratory condition was higher that produced with manure (Barea and Azcon, 1978). Interaction effect of fresh weight of seedling shown significant difference at 9 day after germination whereas dry weight of seedling shown significant difference at 9 DAG, 13 DAG and 15DAG. The highest weight was found from S. rostrata followed by V. radiata with $50 \%$ fertilizer dose from 9 DAG to 15 days after germination (Table 8). On the other hand, control plot seed gave the lowest result compared to other plots. In respect of viability, germination and seedling length in BRRI Dhan66, fertilizer along with green manure $\left(\mathrm{F}_{1} \mathrm{~T}_{1}, \mathrm{~F}_{1} \mathrm{~T}_{2}, \mathrm{~F}_{1} \mathrm{~T}_{4}\right.$ and $\left.\mathrm{F}_{1} \mathrm{~T}_{7}\right)$ showed highest performance (Figure 3 ) and control seed shown disease susceptible (Figure 4). 
Asian J. Med. Biol. Res. 2021, 7 (4)

Table 1. Plant Height $(\mathrm{cm})$, Dry matter $(\mathrm{t} / \mathrm{h})$ and number of nodules plant ${ }^{-1}$ of different green manure crops at 45 days after sowing (DAS).

\begin{tabular}{|l|l|l|l|l|l|l|}
\hline \multirow{2}{*}{ Treatment } & \multicolumn{2}{|l|}{ Plant Height (cm) at 45DAS } & \multicolumn{2}{l|}{ Dry matter (t/h) at 45DAS } & \multicolumn{2}{l|}{ Nodule/plant at 45 DAS } \\
\cline { 2 - 7 } & $\mathbf{1}^{\text {st }}$ Year & $\mathbf{2}^{\text {nd }}$ Year & $\mathbf{1}^{\text {st }}$ Year & $\mathbf{2}^{\text {nd }}$ Year & $\mathbf{1}^{\text {st }}$ year & $\mathbf{2}^{\text {nd }}$ year \\
\hline T1 & $181.97 \mathrm{ab}$ & $186.34 \mathrm{ab}$ & $4.35 \mathrm{bc}$ & $4.66 \mathrm{a}$ & $67.78 \mathrm{~b}$ & $103.76 \mathrm{~b}$ \\
\hline T2 & $220.44 \mathrm{a}$ & $237.67 \mathrm{a}$ & $5.03 \mathrm{ab}$ & $5.2 \mathrm{a}$ & $158.33 \mathrm{a}$ & $224.00 \mathrm{a}$ \\
\hline T3 & $138 \mathrm{bc}$ & $166.67 \mathrm{bO}$ & $5.6 \mathrm{a}$ & $5.2 \mathrm{a}$ & $32.67 \mathrm{~b}$ & $32.67 \mathrm{c}$ \\
\hline T4 & $90 \mathrm{c}$ & $92.44 \mathrm{c}$ & $2.66 \mathrm{~d}$ & $3.06 \mathrm{~b}$ & $23.33 \mathrm{~b}$ & $24.33 \mathrm{c}$ \\
\hline T5 & $88.44 \mathrm{c}$ & $88.44 \mathrm{c}$ & $2.66 \mathrm{~d}$ & $2.53 \mathrm{~b}$ & $23.00 \mathrm{~b}$ & $21.33 \mathrm{c}$ \\
\hline T6 & $178.66 \mathrm{ab}$ & $178.89 \mathrm{~b}$ & $3.86 \mathrm{c}$ & $2.33 \mathrm{~b}$ & $32.33 \mathrm{~b}$ & $20.00 \mathrm{c}$ \\
\hline T7 & $166.44 \mathrm{ab}$ & $165.44 \mathrm{~b}$ & $3.77 \mathrm{c}$ & $2.6 \mathrm{~b}$ & $21.67 \mathrm{~b}$ & $21.00 \mathrm{c}$ \\
\hline T8 & $112 \mathrm{bc}$ & $133 \mathrm{bc}$ & $2.73 \mathrm{~d}$ & $2.63 \mathrm{~b}$ & $19.33 \mathrm{~b}$ & $20.00 \mathrm{c}$ \\
\hline SE $( \pm)$ & 69.95 & 58.36 & 0.713 & 0.575 & 20.46 & 15.82 \\
\hline CV(\%) & 16.53 & 12.98 & 6.46 & 5.09 & 3.62 & 33.19 \\
\hline
\end{tabular}

Here, $\mathrm{T}_{1}=S$. aculeata, $\mathrm{T}_{2}=S$. rostrata, $\mathrm{T}_{3}=C$. juncea, $\mathrm{T}_{4}=V$. radiata, $\mathrm{T}_{5}=V$. mungo,

$\mathrm{T}_{6}=V$. unguiculata, $\mathrm{T}_{7}=L$. leucocephala, $\mathrm{T}_{8}=M$. pudica

In a column, figure(s) followed by the same letter do not differ significantly at $5 \%$ level.

Table 2. Changes of soil fertility status of $P$ and $K$ for the incorporation of different green manuring crops for two year.

\begin{tabular}{|l|l|l|l|l|l|l|}
\hline \multirow{2}{*}{ Treatments } & \multicolumn{3}{|c|}{ P (ppm) } & \multicolumn{3}{c|}{ K (meq 100 $\left.\mathbf{g}^{-1}\right)$} \\
\cline { 2 - 7 } & Initial soil & $\mathbf{1}^{\text {st }}$ year & $\mathbf{2}^{\text {nd }}$ year & Initial soil & $\mathbf{1}^{\text {st }}$ year & $\mathbf{2}^{\text {nd }}$ year \\
\hline $\mathrm{T}_{0}$ & 15.83 & 15.83 & 8.62 & 0.18 & 0.18 & 0.06 \\
$\mathrm{~T}_{1}$ & 15.83 & 12.22 & 12.51 & 0.18 & 0.22 & 0.12 \\
$\mathrm{~T}_{2}$ & 15.83 & 15.00 & 12.61 & 0.18 & 0.22 & 0.10 \\
$\mathrm{~T}_{3}$ & 15.83 & 14.9 & 12.33 & 0.18 & 0.21 & 0.10 \\
$\mathrm{~T}_{4}$ & 15.83 & 11.45 & 12.31 & 0.18 & 0.20 & 0.11 \\
$\mathrm{~T}_{5}$ & 15.83 & 12.09 & 12.60 & 0.18 & 0.18 & 0.10 \\
$\mathrm{~T}_{6}$ & 15.83 & 11.86 & 12.31 & 0.18 & 0.18 & 0.09 \\
$\mathrm{~T}_{7}$ & 15.83 & 12.01 & 12.64 & 0.18 & 0.19 & 0.16 \\
$\mathrm{~T}_{8}$ & 15.83 & 13.54 & 12.44 & 0.18 & 0.20 & 0.18 \\
\hline
\end{tabular}

Here, $\mathrm{T}_{1}=S$. aculeata, $\mathrm{T}_{2}=S$. rostrata, $\mathrm{T}_{3}=C$. juncea, $\mathrm{T}_{4}=V$. radiata, $\mathrm{T}_{5}=V$. mungo,

$\mathrm{T}_{6}=V$. unguiculata, $\mathrm{T}_{7}=L$. leucocephala, $\mathrm{T}_{8}=M$. pudica 
Asian J. Med. Biol. Res. 2021, 7 (4)

Table 3. Changes in post-harvest soil nutrient status (OM and total $N$ ) of rice soil as affected by green manures and nitrogen levels.

\begin{tabular}{|c|c|c|c|c|c|c|c|}
\hline \multirow[t]{2}{*}{ Treatments } & \multirow[t]{2}{*}{$\begin{array}{l}\mathbf{N} \text { level } \\
(\mathrm{kg} / \mathrm{h})\end{array}$} & Initial Soil & \multicolumn{2}{|c|}{ Soil Organic Matter } & $\begin{array}{l}\text { Initial } \\
\text { Soil } \\
\end{array}$ & \multicolumn{2}{|c|}{ Total N (\%) } \\
\hline & & \multirow{19}{*}{1.01} & $1^{\text {st }}$ year & $2^{\text {nd }}$ year & \multirow{19}{*}{0.04} & $1^{\text {st }}$ year & $2^{\text {nd }}$ year \\
\hline \multirow[t]{2}{*}{ T0 } & F1 & & 1.01 & 1.00 & & 0.04 & 0.05 \\
\hline & F2 & & 0.54 & 1.00 & & 0.05 & 0.07 \\
\hline \multirow[t]{2}{*}{ T1 } & F1 & & 1.21 & 1.97 & & 0.06 & 0.09 \\
\hline & F2 & & 1.41 & 1.72 & & 0.05 & 0.10 \\
\hline \multirow[t]{2}{*}{$\mathrm{T} 2$} & F1 & & 1.02 & 2.01 & & 0.08 & 0.11 \\
\hline & F2 & & 1.14 & 1.77 & & 0.07 & 0.10 \\
\hline \multirow[t]{2}{*}{$\mathrm{T} 3$} & F1 & & 1.14 & 1.80 & & 0.06 & 0.11 \\
\hline & F2 & & 1.03 & 1.77 & & 0.08 & 0.10 \\
\hline \multirow[t]{2}{*}{$\mathrm{T} 4$} & F1 & & 1.08 & 1.80 & & 0.05 & 0.10 \\
\hline & F2 & & 0.81 & 1.72 & & 0.05 & 0.10 \\
\hline \multirow[t]{2}{*}{ T5 } & F1 & & 1.75 & 1.56 & & 0.09 & 0.09 \\
\hline & F2 & & 0.87 & 1.72 & & 0.05 & 0.10 \\
\hline \multirow[t]{2}{*}{ T6 } & F1 & & 0.87 & 1.72 & & 0.05 & 0.10 \\
\hline & F2 & & 1.21 & 1.56 & & 0.04 & 0.09 \\
\hline \multirow[t]{2}{*}{$\mathrm{T} 7$} & F1 & & 0.94 & 1.76 & & 0.05 & 0.11 \\
\hline & F2 & & 0.94 & 1.77 & & 0.05 & 0.10 \\
\hline \multirow[t]{2}{*}{ T8 } & F1 & & 0.94 & 1.23 & & 0.05 & 0.11 \\
\hline & F2 & & 0.87 & 1.51 & & 0.06 & 0.08 \\
\hline
\end{tabular}

Here, F1 = Recommended dose for N in 2015 and NPK in 2016, F2 = Half of recommended dose for N in 2015 and NPK in 2016, $\mathrm{T} 0=\mathrm{Control}, \mathrm{T} 1=S$. aculeata, $\mathrm{T} 2=S$. rostrata, $\mathrm{T} 3=C$. juncea, $\mathrm{T} 4=V$. radiata, $\mathrm{T} 5=V$. mungo, $\mathrm{T} 6=V$. unguiculat $a$, $\mathrm{T} 7=$ L. leucocephala, $\mathrm{T} 8=M$. pudica, In a column, figure(s) followed by same letter do not differ significantly at $5 \%$ level

Table 4. Changes in post-harvest soil nutrient status ( $K$ and $P$ ) of rice as affected by green manures and nitrogen levels.

\begin{tabular}{|c|c|c|c|c|c|}
\hline \multirow[t]{2}{*}{ Treatments } & \multirow{2}{*}{$\begin{array}{l}\text { N levels } \\
(\mathrm{kg} / \mathrm{ha})\end{array}$} & \multicolumn{2}{|c|}{ Soil K (meq $\left.100 \mathrm{~g}^{-1}\right)$} & \multicolumn{2}{|c|}{ Available P (ppm) } \\
\hline & & 2015 & 2016 & 2015 & 2016 \\
\hline \multirow[t]{2}{*}{ Control } & $\mathrm{F} 1$ & 0.09 & 0.10 & 3.00 & 23.40 \\
\hline & $\mathrm{F} 2$ & 0.09 & 0.09 & 3.06 & 21.86 \\
\hline \multirow[t]{2}{*}{ S. aculeata } & $\mathrm{F} 1$ & 0.10 & 0.079 & 4.33 & 31.20 \\
\hline & $\mathrm{F} 2$ & 0.10 & 0.10 & 3.67 & 33.17 \\
\hline \multirow[t]{2}{*}{ S. rostrata } & $\mathrm{F} 1$ & 0.11 & 0.16 & 4.71 & 39.00 \\
\hline & F2 & 0.09 & 0.10 & 3.92 & 33.00 \\
\hline \multirow{2}{*}{ C. juncea } & $\mathrm{F} 1$ & 0.10 & 0.10 & 4.59 & 28.00 \\
\hline & $\mathrm{F} 2$ & 0.10 & 0.10 & 3.91 & 31.51 \\
\hline \multirow[t]{2}{*}{ V. radiata } & $\mathrm{F} 1$ & 0.10 & 0.11 & 4.14 & 27.97 \\
\hline & $\mathrm{F} 2$ & 0.09 & 0.10 & 3.27 & 27.04 \\
\hline \multirow[t]{2}{*}{ V. mungo } & $\mathrm{F} 1$ & 0.10 & 0.06 & 3.89 & 30.77 \\
\hline & $\mathrm{F} 2$ & 0.10 & 0.10 & 3.06 & 27.70 \\
\hline \multirow[t]{2}{*}{ V. unguiculata } & $\mathrm{F} 1$ & 0.10 & 0.07 & 3.91 & 26.00 \\
\hline & $\mathrm{F} 2$ & 0.09 & 0.09 & 3.27 & 23.00 \\
\hline \multirow[t]{2}{*}{ L. leucocephala } & $\mathrm{F} 1$ & 0.10 & 0.09 & 4.22 & 24.00 \\
\hline & F2 & 0.11 & 0.10 & 3.44 & 22.44 \\
\hline \multirow[t]{2}{*}{ M. pudica } & $\mathrm{F} 1$ & 0.10 & 0.10 & 4.11 & 27.38 \\
\hline & F2 & 0.12 & 0.08 & 3.72 & 22.00 \\
\hline
\end{tabular}

Here, F1= Recommended dose for N in 2015 and NPK in 2016, F2= Half of recommended dose for N in 2015 and NPK in 2016 
Table 5. Effect of green manuring crops and nitrogen levels on leaf chlorophyll content (SPAD value) and protein content $(\%)$ of $T$. aman rice.

\begin{tabular}{|c|c|c|c|}
\hline \multirow[t]{2}{*}{ Interactions } & \multicolumn{2}{|c|}{ SPAD value (\%) } & \multirow{2}{*}{$\begin{array}{l}\text { Protein content }(\%) \\
2^{\text {nd }} \text { year }\end{array}$} \\
\hline & $1^{\text {st }}$ year & $2^{\text {nd }}$ year & \\
\hline F1 T0 & 43.83 & 36.71 & $7.85 \mathrm{~cd}$ \\
\hline $\mathrm{F} 1 \mathrm{~T} 1$ & 42.28 & 39.05 & $8.17 \mathrm{a}$ \\
\hline $\mathrm{F} 1 \mathrm{~T} 2$ & 43.07 & 36.76 & $8.28 \mathrm{a}$ \\
\hline F1 T3 & 40.35 & 38.70 & $8.23 \mathrm{a}$ \\
\hline $\mathrm{F} 1 \mathrm{~T} 4$ & 39.37 & 38.93 & $8.04 \mathrm{a}$ \\
\hline F1 T5 & 44.40 & 38.43 & $8.40 \mathrm{ab}$ \\
\hline F1 T6 & 42.58 & 38.36 & $8.10 \mathrm{a}-\mathrm{c}$ \\
\hline F1 T7 & 42.94 & 36.10 & $8.09 a-c$ \\
\hline F1T8 & 40.93 & 36.53 & $8.26 a-c$ \\
\hline F 2T0 & 40.28 & 37.65 & $7.54 \mathrm{~d}$ \\
\hline $\mathrm{F} 2 \mathrm{~T} 1$ & 42.21 & 36.60 & $8.21 \mathrm{a}-\mathrm{c}$ \\
\hline $\mathrm{F} 2 \mathrm{~T} 2$ & 44.47 & 36.60 & $8.54 \mathrm{a}$ \\
\hline F $2 \mathrm{~T} 3$ & 43.40 & 36.33 & $8.22 \mathrm{a}-\mathrm{c}$ \\
\hline $\mathrm{F} 2 \mathrm{~T} 4$ & 42.57 & 36.66 & $8.04 \mathrm{a}-\mathrm{d}$ \\
\hline F2 T5 & 42.74 & 37.33 & $8.15 a-c$ \\
\hline F 2T6 & 41.64 & 37.66 & $8.06 a-d$ \\
\hline F $2 \mathrm{~T} 7$ & 43.00 & 36.33 & $8.01 \mathrm{~b}-\mathrm{d}$ \\
\hline $\mathrm{F} 2 \mathrm{~T} 8$ & 40.52 & 36.33 & $8.20 \mathrm{a}-\mathrm{c}$ \\
\hline SE $( \pm)$ & NS & NS & 0.056 \\
\hline $\mathrm{CV}(\%)$ & 6.37 & 5.64 & 1.99 \\
\hline
\end{tabular}

Here, F1= Recommended dose for NPK, F2 = Half of recommended doses of NPK, Here, T0=Control, T1=S. aculeata, $\mathrm{T} 2=S$. rostrata, $\mathrm{T} 3=C$. juncea, $\mathrm{T} 4=V$. radiata, $\mathrm{T} 5=V$. mungo, $\mathrm{T} 6=V$. unguiculat $a, \mathrm{~T} 7=L$. leucocephala, $\mathrm{T} 8=M$. pudica, $\mathrm{NS}$ $=$ Not Significant. In a column, figure(s) followed by same letter do not differ significantly at $5 \%$ level.

Table 6. Interaction effect of fertilizer levels and different green manuring crops on grain yield, straw yield and 1000-grain weight of transplant aman rice in two years.

\begin{tabular}{|c|c|c|c|c|}
\hline \multirow[t]{2}{*}{ Interactions } & \multicolumn{2}{|c|}{ Grain yield ( tha ${ }^{-1}$ ) } & \multicolumn{2}{|c|}{ 1000-grain wt. (g) } \\
\hline & 1st year & 2nd year & 1st year & 2nd year \\
\hline F1 T0 & $3.10 \mathrm{f}$ & $3.43 \mathrm{~b}$ & $21.36 \mathrm{~b}$ & $22.08 \mathrm{~b}$ \\
\hline $\mathrm{F} 1 \mathrm{~T} 1$ & $5.13 a-c$ & $5.20 \mathrm{a}$ & $23.38 \mathrm{ab}$ & $23.91 \mathrm{a}$ \\
\hline $\mathrm{F} 1 \mathrm{~T} 2$ & $5.23 \mathrm{a}$ & $5.56 \mathrm{a}$ & $24.11 \mathrm{a}$ & 23.94 \\
\hline F1 T3 & $4.93 \mathrm{a}-\mathrm{d}$ & $5.30 \mathrm{a}$ & $23.56 \mathrm{ab}$ & $23.69 \mathrm{a}$ \\
\hline $\mathrm{F} 1 \mathrm{~T} 4$ & $3.56 f$ & $4.73 \mathrm{a}$ & $22.78 \mathrm{ab}$ & $23.41 \mathrm{ab}$ \\
\hline F1 T5 & $4.20 \mathrm{a}-\mathrm{f}$ & $4.73 \mathrm{a}$ & $22.59 \mathrm{ab}$ & $22.92 \mathrm{ab}$ \\
\hline F1 T6 & $4.76 a-d$ & $5.13 \mathrm{a}$ & $23.08 \mathrm{ab}$ & $23.85 \mathrm{a}$ \\
\hline F1 T7 & $3.96 b-f$ & $4.76 \mathrm{a}$ & $23.23 \mathrm{ab}$ & $23.50 \mathrm{ab}$ \\
\hline F1T8 & $3.80 \mathrm{~d}-\mathrm{f}$ & $4.83 \mathrm{a}$ & $23.50 \mathrm{ab}$ & $23.75 \mathrm{a}$ \\
\hline F2T0 & $3.68 \mathrm{~d}-\mathrm{f}$ & $3.97 \mathrm{ab}$ & $22.86 \mathrm{ab}$ & $23.07 \mathrm{ab}$ \\
\hline $\mathrm{F} 2 \mathrm{~T} 1$ & $4.86 \mathrm{a}-\mathrm{d}$ & $5.30 \mathrm{a}$ & $23.07 \mathrm{ab}$ & $23.53 \mathrm{a}$ \\
\hline $\mathrm{F} 2 \mathrm{~T} 2$ & $5.16 \mathrm{ab}$ & $5.11 \mathrm{a}$ & $23.54 \mathrm{ab}$ & $23.87 \mathrm{a}$ \\
\hline F2 T3 & $4.43 \mathrm{a}-\mathrm{e}$ & $5.13 \mathrm{a}$ & $23.60 \mathrm{ab}$ & $23.80 \mathrm{a}$ \\
\hline $\mathrm{F} 2 \mathrm{~T} 4$ & $3.90 \mathrm{~d}-\mathrm{f}$ & $4.45 \mathrm{ab}$ & $23.26 \mathrm{ab}$ & $23.51 \mathrm{a}$ \\
\hline F2 T5 & $3.93 \mathrm{~d}-\mathrm{f}$ & $4.26 \mathrm{ab}$ & $22.73 \mathrm{ab}$ & 23.39ab \\
\hline F2T6 & $4.73 \mathrm{a}-\mathrm{e}$ & $5.03 \mathrm{a}$ & $21.71 \mathrm{ab}$ & $23.44 \mathrm{ab}$ \\
\hline $\mathrm{F} 2 \mathrm{~T} 7$ & 4.26a-f & $4.53 \mathrm{ab}$ & $21.88 \mathrm{ab}$ & $23.26 \mathrm{ab}$ \\
\hline F2T8 & $4.66 \mathrm{a}-\mathrm{e}$ & $4.13 \mathrm{ab}$ & $23.33 \mathrm{ab}$ & $23.33 \mathrm{ab}$ \\
\hline (SE ( \pm$)$ & 0.283 & 0.296 & 0.663 & 0.340 \\
\hline CV (\%) & 8.87 & 8.06 & 3.63 & 1.96 \\
\hline
\end{tabular}

Here, F1= Recommended dose for N in 2015 and NPK in 2016, F2= Half of recommended dose for N in 2015 and NPK in 2016

Here, $\mathrm{T} 0=$ Control, $\mathrm{T} 1=S$. aculeata, $\mathrm{T} 2=S$. rostrata, $\mathrm{T} 3=C$. juncea, $\mathrm{T} 4=V$. radiata, $\mathrm{T} 5=V$. mungo, T6=V. unguiculat a, T7=L. leucocephala, $\mathrm{T} 8=M$. pudica, NS $=$ Not Significant

In a column, figure(s) followed by same letter do not differ significantly at $5 \%$ level. 
Table 7. Interaction effect of fertilizer levels and green manuring crops on seed quality characteristics of rice seed under laboratory condition.

\begin{tabular}{|c|c|c|c|c|c|c|c|c|c|c|}
\hline \multirow[t]{2}{*}{ ntInteractions } & \multirow{2}{*}{$\begin{array}{l}\text { Germination } \\
\%\end{array}$} & \multirow{2}{*}{$\begin{array}{l}\text { Germination } \\
\text { energy }(\%)\end{array}$} & \multicolumn{4}{|c|}{ Cotyledon length $(\mathrm{cm})$} & \multicolumn{4}{|c|}{ Radicle length $(\mathrm{cm})$} \\
\hline & & & 9DAG & 11DAG & 13DAG & 15DAG & 9DAG & 11DAG & 13DAG & 15DAG \\
\hline F1 T0 & 86.67 & 40.00 & 2.30 & $2.61 \mathrm{c}$ & $4.05 b$ & 5.30 & 5.01 & $5.74 \mathrm{bcd}$ & 5.63 & 5.78 \\
\hline $\mathrm{F} 1 \mathrm{~T} 1$ & 98.33 & 55.00 & 3.20 & $3.86 \mathrm{a}-\mathrm{c}$ & $4.62 \mathrm{ab}$ & 5.28 & 5.40 & $6.30 \mathrm{a}-\mathrm{d}$ & 6.46 & 8.00 \\
\hline $\mathrm{F} 1 \mathrm{~T} 2$ & 96.70 & 66.66 & 3.20 & $4.88 \mathrm{ab}$ & $7.16 \mathrm{a}$ & 7.63 & 6.13 & $7.56 \mathrm{a}-\mathrm{c}$ & 8.00 & 9.13 \\
\hline $\mathrm{F} 1 \mathrm{~T} 3$ & 91.67 & 48.33 & 3.03 & $4.05 \mathrm{a}-\mathrm{c}$ & $5.63 \mathrm{ab}$ & 5.98 & 5.55 & $6.36 \mathrm{a}-\mathrm{d}$ & 7.53 & 8.06 \\
\hline $\mathrm{F} 1 \mathrm{~T} 4$ & 88.33 & 45.00 & 2.51 & $4.53 \mathrm{a}-\mathrm{c}$ & $5.98 \mathrm{ab}$ & 6.06 & 5.56 & 7.10a-d & 7.46 & 7.93 \\
\hline F1 T5 & 98.33 & 66.66 & 3.10 & $4.70 \mathrm{ab}$ & $5.61 \mathrm{ab}$ & 6.05 & 5.66 & $6.32 \mathrm{a}-\mathrm{d}$ & 6.73 & 6.57 \\
\hline F1 T6 & 98.33 & 48.33 & 2.80 & $4.56 \mathrm{a}-\mathrm{c}$ & $5.42 \mathrm{ab}$ & 5.90 & 4.97 & $6.60 a-d$ & 7.46 & 7.23 \\
\hline $\mathrm{F} 1 \mathrm{~T} 7$ & 95.00 & 58.33 & 2.96 & $4.70 \mathrm{ab}$ & $5.30 \mathrm{ab}$ & 5.67 & 4.86 & $7.13 \mathrm{a}-\mathrm{d}$ & 6.83 & 7.26 \\
\hline F1T8 & 88.33 & 56.66 & 3.26 & $4.36 \mathrm{a}-\mathrm{c}$ & $5.17 \mathrm{ab}$ & 5.20 & 5.76 & $6.17 \mathrm{a}-\mathrm{d}$ & 6.00 & 6.30 \\
\hline F 2T0 & 89.17 & 45.00 & 2.42 & $2.76 b c$ & $4.10 \mathrm{ab}$ & 4.20 & 3.96 & $4.94 d$ & 5.69 & 5.84 \\
\hline $\mathrm{F} 2 \mathrm{~T} 1$ & 95.00 & 80.00 & 3.63 & $4.63 \mathrm{ab}$ & $6.56 \mathrm{ab}$ & 6.90 & 5.67 & $7.70 \mathrm{ab}$ & 7.66 & 7.33 \\
\hline $\mathrm{F} 2 \mathrm{~T} 2$ & 96.67 & 70.00 & 3.53 & $4.90 \mathrm{ab}$ & $5.56 \mathrm{ab}$ & 6.10 & 5.98 & $7.23 \mathrm{abc}$ & 7.80 & 7.86 \\
\hline F 2 T3 & 96.67 & 53.33 & 3.37 & $4.18 \mathrm{a}-\mathrm{c}$ & $5.95 \mathrm{ab}$ & 5.69 & 5.97 & $6.35 \mathrm{a}-\mathrm{d}$ & 6.33 & 6.95 \\
\hline $\mathrm{F} 2 \mathrm{~T} 4$ & 100.00 & 58.33 & 3.10 & $3.68 \mathrm{a}-\mathrm{c}$ & $4.64 \mathrm{ab}$ & 4.90 & 5.40 & $5.53 \mathrm{~cd}$ & 6.48 & 6.36 \\
\hline $\mathrm{F} 2 \mathrm{~T} 5$ & 93.33 & 56.66 & 2.69 & $3.39 \mathrm{a}-\mathrm{c}$ & $4.76 \mathrm{ab}$ & 5.26 & 4.94 & $5.10 \mathrm{~d}$ & 6.54 & 6.17 \\
\hline F 2T6 & 93.33 & 63.33 & 3.61 & $5.27 \mathrm{a}$ & $5.44 \mathrm{ab}$ & 6.45 & 6.55 & $6.17 \mathrm{a}-\mathrm{d}$ & 6.93 & 9.26 \\
\hline F 2 T7 & 98.33 & 51.66 & 3.32 & $4.64 \mathrm{ab}$ & $5.92 \mathrm{ab}$ & 6.28 & 5.66 & $6.52 \mathrm{a}-\mathrm{d}$ & 7.50 & 8.07 \\
\hline $\mathrm{F} 2 \mathrm{~T} 8$ & 100 & 66.66 & 2.86 & $3.83 \mathrm{abc}$ & $4.83 \mathrm{ab}$ & 5.35 & 5.35 & $6.52 \mathrm{a}-\mathrm{d}$ & 5.60 & 6.28 \\
\hline $\operatorname{LSD}(0.05)$ & NS & NS & NS & 1.57 & 2.79 & NS & NS & 1.84 & NS & NS \\
\hline $\mathrm{CV}(\%)$ & 5.78 & 26.29 & 19.69 & 11.41 & 15.98 & 18.15 & 16.12 & 9.70 & 12.86 & 21.17 \\
\hline
\end{tabular}

$\mathrm{F} 1=100 \%$ Recommended fertilizer dose, $\mathrm{F} 2=50 \%$ Fertilizer dose

Here, $\mathrm{T} 0=\mathrm{Control}, \mathrm{T} 1=S$. aculeata, $\mathrm{T} 2=S$. rostrata, $\mathrm{T} 3=C$. juncea, $\mathrm{T} 4=V$. radiata, $\mathrm{T} 5=V$. mungo, T6=V. unguiculata, $\mathrm{T} 7=L$. leucocephala, $\mathrm{T} 8=M$. pudica

In a column, figures having similar letter(s) do not differ significantly whereas figures bearing dissimilar letter differ significantly. 
Asian J. Med. Biol. Res. 2021, 7 (4)

Table 8. Interaction effect of fertilizer levels and green manuring crops on seed quality (fresh weight and dry weight) of rice seed.

\begin{tabular}{|c|c|c|c|c|c|c|c|c|}
\hline \multirow[t]{2}{*}{ Interactions } & \multicolumn{4}{|c|}{ Fresh wt. (g) } & \multicolumn{4}{|c|}{ Dry wt (g) } \\
\hline & 9 DAG & 11DAG & 13DAG & 15DAG & 9DAG & 11DAG & 13DAG & 15DAG \\
\hline $\mathrm{F}_{1} \mathrm{~T}_{0}$ & $0.11 \mathrm{~b}$ & 0.175 & 0.20 & 0.21 & $0.03 c$ & 0.05 & $0.05 a b$ & $0.05 \mathrm{~b}$ \\
\hline $\mathrm{F}_{1} \mathrm{~T}_{1}$ & $0.15 \mathrm{ab}$ & 0.19 & 0.23 & 0.27 & $0.05 a-c$ & 0.05 & $0.05 \mathrm{ab}$ & $0.06 \mathrm{ab}$ \\
\hline$F_{1} T_{2}$ & $0.21 \mathrm{a}$ & 0.24 & 0.29 & 0.42 & $0.05 a$ & 0.06 & $0.06 a b$ & $0.06 a b$ \\
\hline $\mathrm{F}_{1} \mathrm{~T}_{3}$ & $0.16 a b$ & 0.19 & 0.21 & 0.27 & $0.04 a-c$ & 0.05 & $0.06 a b$ & $0.06 \mathrm{ab}$ \\
\hline $\mathrm{F}_{1} \mathrm{~T}_{4}$ & $0.20 \mathrm{ab}$ & 0.23 & 0.27 & 0.31 & $0.04 \mathrm{ab}$ & 0.05 & $0.05 a b$ & $0.05 \mathrm{ab}$ \\
\hline $\mathrm{F}_{1} \mathrm{~T}_{5}$ & $0.17 \mathrm{ab}$ & 0.18 & 0.26 & 0.27 & $0.4 \mathrm{a}-\mathrm{c}$ & 0.05 & $0.06 \mathrm{ab}$ & $0.06 \mathrm{ab}$ \\
\hline $\mathrm{F}_{1} \mathrm{~T}_{6}$ & $0.18 \mathrm{ab}$ & 0.20 & 0.24 & 0.24 & $0.05 a-c$ & 0.05 & $0.05 \mathrm{ab}$ & $0.05 \mathrm{ab}$ \\
\hline $\mathrm{F}_{1} \mathrm{~T}_{7}$ & $0.14 \mathrm{ab}$ & 0.21 & 0.23 & 0.29 & $0.05 \mathrm{ab}$ & 0.05 & $0.06 \mathrm{ab}$ & $0.06 a b$ \\
\hline $\mathrm{F}_{1} \mathrm{~T}_{8}$ & $0.15 \mathrm{ab}$ & 0.17 & 0.26 & 0.27 & $0.05 \mathrm{ab}$ & 0.05 & $0.05 a b$ & $0.06 \mathrm{ab}$ \\
\hline $\mathrm{F}_{2} \mathrm{~T}_{0}$ & $0.12 \mathrm{ab}$ & 0.17 & 0.21 & 0.29 & 0.039 & 0.04 & $0.04 \mathrm{~b}$ & $0.05 b$ \\
\hline $\mathrm{F}_{2} \mathrm{~T}_{1}$ & $0.18 \mathrm{ab}$ & 0.21 & 0.26 & 0.27 & $0.05 \mathrm{a}$ & 0.06 & $0.06 \mathrm{ab}$ & $0.06 \mathrm{ab}$ \\
\hline $\mathrm{F}_{2} \mathrm{~T}_{2}$ & $0.22 \mathrm{a}$ & 0.23 & 0.26 & 0.24 & $0.05 \mathrm{ab}$ & 0.06 & $0.07 \mathrm{a}$ & $0.07 \mathrm{a}$ \\
\hline $\mathrm{F}_{2} \mathrm{~T}_{3}$ & $0.22 \mathrm{a}$ & 0.21 & 0.24 & 0.29 & $0.05 \mathrm{ab}$ & 0.05 & $0.05 \mathrm{ab}$ & $0.06 \mathrm{ab}$ \\
\hline $\mathrm{F}_{2} \mathrm{~T}_{4}$ & $0.16 \mathrm{ab}$ & 0.17 & 0.24 & 0.30 & $0.04 a-c$ & 0.05 & $0.06 \mathrm{ab}$ & $0.05 \mathrm{ab}$ \\
\hline $\mathrm{F}_{2} \mathrm{~T}_{5}$ & $0.15 \mathrm{ab}$ & 0.18 & 0.23 & 0.29 & $0.05 \mathrm{a}$ & 0.05 & $0.06 \mathrm{ab}$ & $0.06 \mathrm{ab}$ \\
\hline $\mathrm{F}_{2} \mathrm{~T}_{6}$ & $0.18 \mathrm{ab}$ & 0.22 & 0.25 & 0.33 & $0.04 a b$ & 0.05 & $0.05 \mathrm{ab}$ & $0.05 \mathrm{~b}$ \\
\hline $\mathrm{F}_{2} \mathrm{~T}_{7}$ & $0.18 \mathrm{ab}$ & 0.23 & 0.30 & 0.32 & $0.05 \mathrm{a}-\mathrm{c}$ & 0.05 & $0.05 \mathrm{ab}$ & $0.05 b$ \\
\hline $\mathrm{F}_{2} \mathrm{~T}_{8}$ & $0.17 \mathrm{ab}$ & 0.18 & 0.21 & 0.24 & $0.05 \mathrm{a}-\mathrm{c}$ & 0.05 & $0.05 \mathrm{ab}$ & $0.05 \mathrm{ab}$ \\
\hline (SE ( \pm ) & 0.0227 & NS & NS & NS & 3.0E-03 & NS & 5E-05 & $4.3 \mathrm{E}-03$ \\
\hline $\mathrm{CV}(\%)$ & 17.65 & 16.31 & 18.26 & 26.74 & 8.25 & 11.37 & 10.94 & 9.55 \\
\hline
\end{tabular}

$\mathrm{F}_{1}=100 \%$ Recommended fertilizer dose, $\mathrm{F}_{2}=50 \%$ Fertilizer dose, NS= Non Significant, Here, $\mathrm{T}_{0}=$ Control, $\mathrm{T}_{1}=S$. aculeata, $\mathrm{T}_{2}=S$. rostrata, $\mathrm{T}_{3}=C$. juncea, $\mathrm{T}_{4}=V$. radiata, $\mathrm{T}_{5}=V$. mungo, $\mathrm{T}_{6}=V$. unguiculata, $\mathrm{T}_{7}=L$. leucocephala, $\mathrm{T}_{8}=M$. pudica

In a column, figures having similar letter(s) do not differ significantly whereas figures bearing dissimilar letter differ significantly 
Initial soil $\quad \square$ 1st year $\quad$ 2nd year

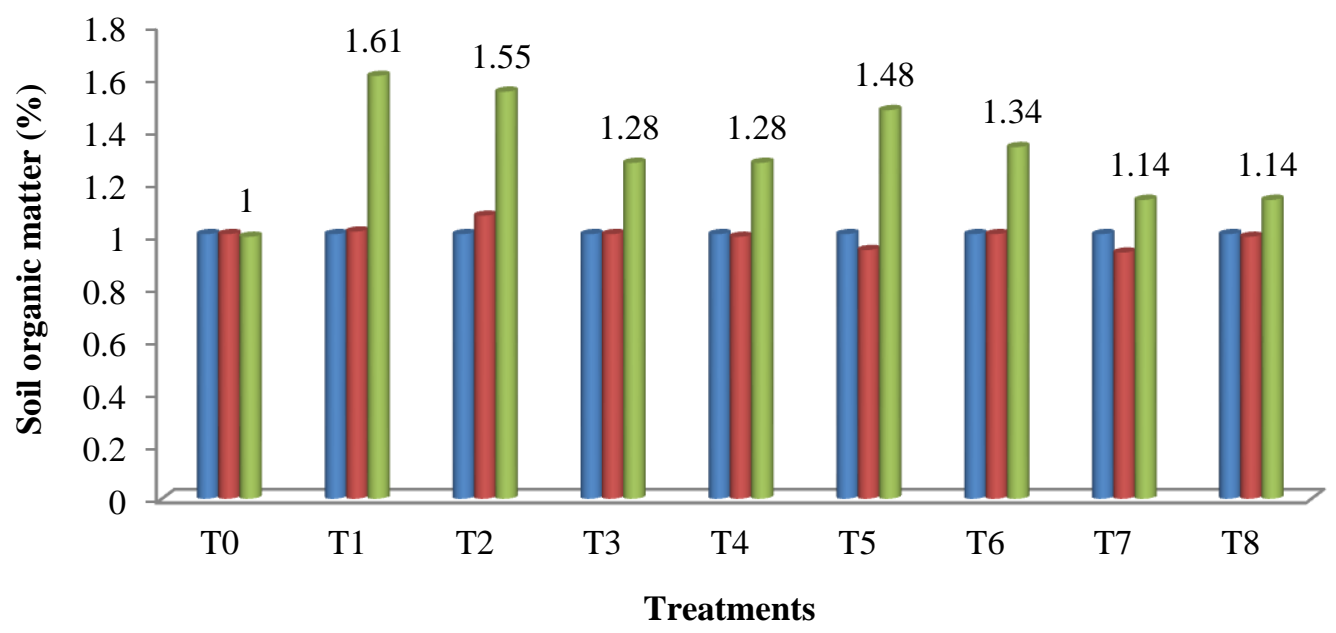

Here, $\mathrm{T}_{1}=S$. aculeata, $\mathrm{T}_{2}=S$. rostrata, $\mathrm{T}_{3}=C$. juncea, $\mathrm{T}_{4}=V$. radiata, $\mathrm{T}_{5}=V$. mungo, $\mathrm{T}_{6}=V$. unguiculata, $\mathrm{T}_{7}=L$. leucocephala, $\mathrm{T}_{8}=M$. pudica

Figure 1. Effect of different green manuring crops on organic matter content of pre-sown rice soil.

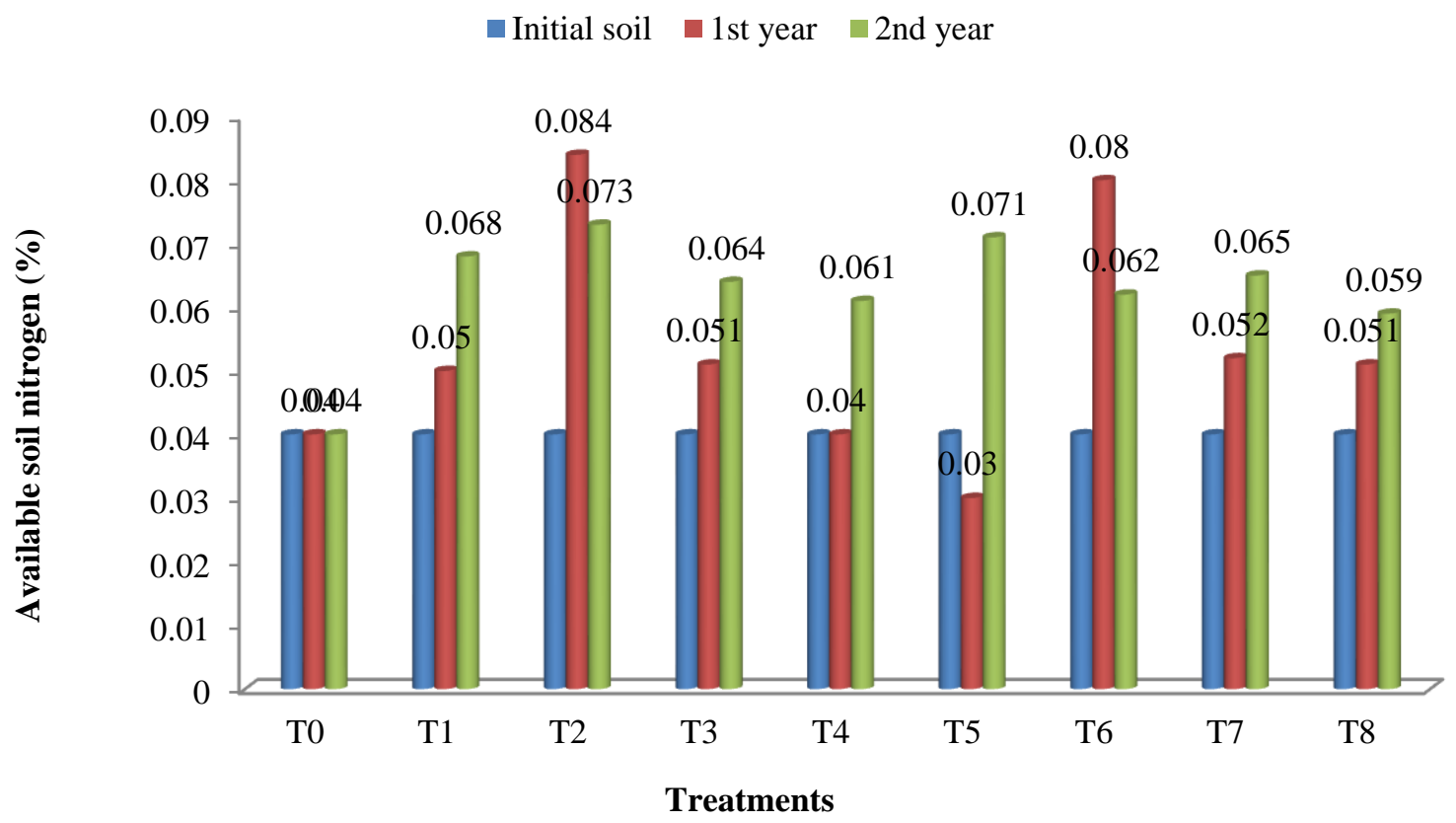

Here, $\mathrm{T}_{1}=S$. aculeata, $\mathrm{T}_{2}=S$. rostrata, $\mathrm{T}_{3}=C$. juncea, $\mathrm{T}_{4}=V$. radiata, $\mathrm{T}_{5}=V$. mungo, $\mathrm{T}_{6}=V$. unguiculata, $\mathrm{T}_{7}=L$. leucocephala, $\mathrm{T}_{8}=M$. pudica

Figure 2. Effect of different green manuring crops on total nitrogen content of pre-sown rice soil. 


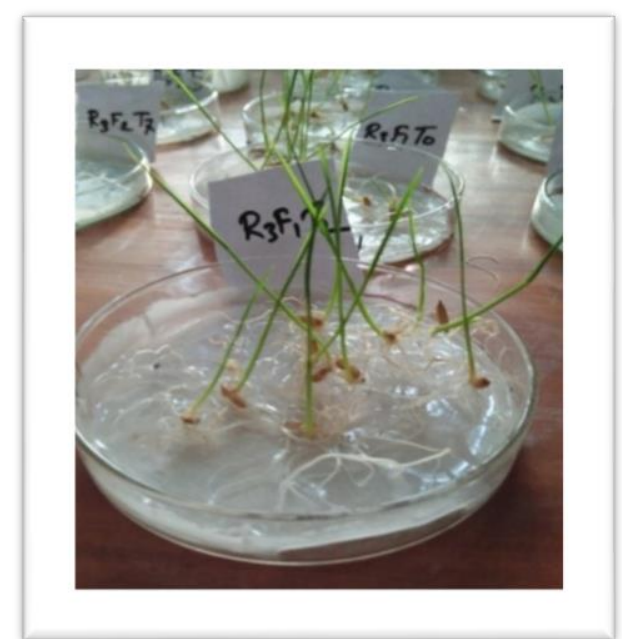

Sesbania rostrata

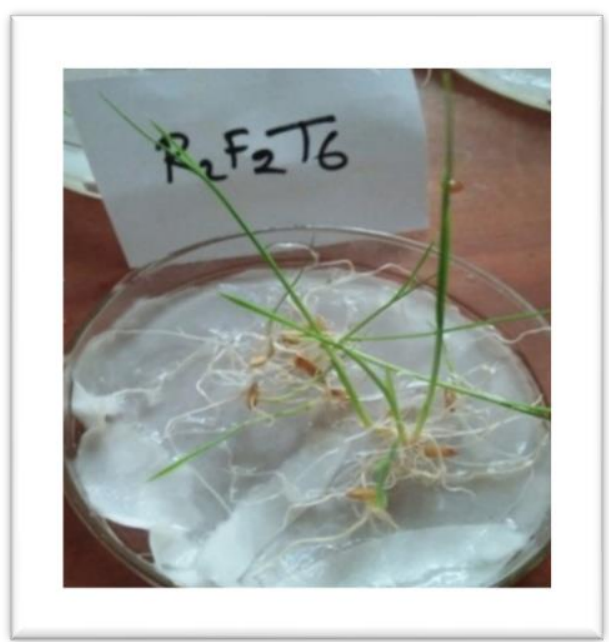

Vigna unguiculata

Figure 3. Vigorous growth of Sesbania rostrata and Vigna unguiculata treated rice seeds unde laboratory condition.

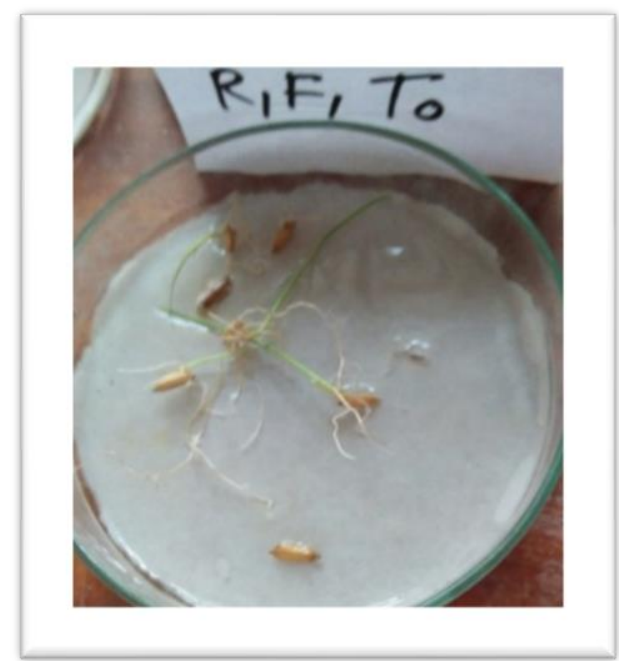

Control

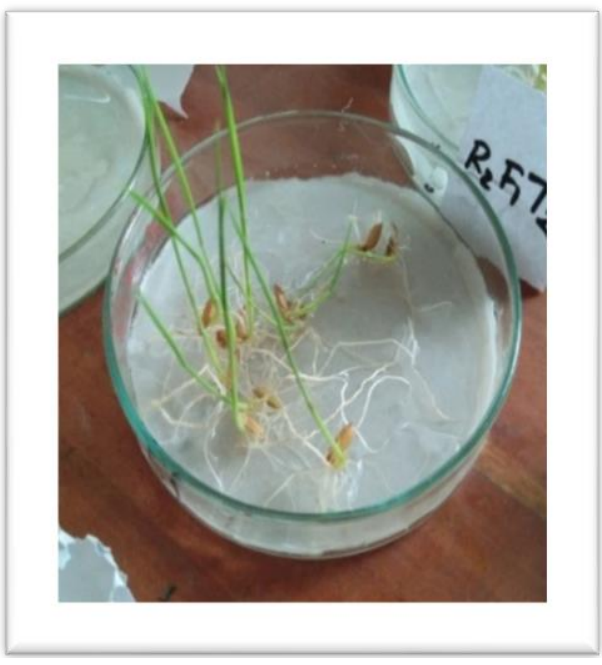

S. rostrata

Figure 4. Comparision between control and Sesbania rostrata treated rice seeds under laboratory condition.

\section{Conclusions}

Among different green manures, S. rostrata, S. aculeata, C. juncea and $V$. unguiculata green manures with $50 \%$ of recommended chemical fertilizer dose significantly increased rice yield and nutrient added quality in fallow land (pre sown rice soil) and post-harvest soil through adding biomass, N, P and K to the soil. These aforementioned green manures could be practiced in cultivable fallow land (after boro cultivation our land remain fallow for two months) for nitrogen as well as NK fertilizer saving and increased the soil fertility, rice yield and grown $\mathrm{T}$. aman seed quality.

\section{Acknowledgments}

The financial support of the authority of Syed Momena Montaj Foundation during research work is gratefully acknowledged.

\section{Conflict of interest}

None to declare. 
Authors' contribution

I.J. Irin: conceptualization, methodology, data collection, analysis and manuscript writing; P.K. Biswas: supervision, reviewing and editing; M.A. Khan: supervision, reviewing and editing. All authors have read and approved the final manuscript.

\section{References}

Ali RI, TH Awan, M Ahmed, MU Saleem and M Akhtar, 2012. Diversification of rice-based cropping systems to improve soil fertility, sustainable productivity and economics. The J. Anim. Plant Sci., 22: 108-112.

Becker M, M Ali, JK Ladha and JCG Ottow 1995. Agronomic and economic evaluation of Sesbania rostrata green manure establishment in irrigated rice. Field Crops Res., 40: 135-141.

Biswas TD and SK Mukherjee, 1991. Textbook of Soil Science. Tata McGraw-Hill Publishing Company Limited, New Delhi.

Biswas PK, M Akhteruzzaman, A Quasem and AKMR Amin, 1996. Effect of decomposition period of Sesbania aculeata and nitrogen doses on rice yield and soil fertility. Progress. Agric., 7: 107-109.

Caballero R, M Arauzo and PJ Hernaiz, 1996. Accumulation and redistribution of mineral elements in common vetch during pod filling. Agron J., 38: 801-805.

Chen XH and B Zhao, 2009. Arbuscular mycorrhizal fungi mediated uptake of nutrient elements by Chinese milk vetch (Astragalus sinicus L.) grown in lanthanum spiked soil. Biol Fertil Soils., 45:675-678.

Chadha M L, TS Brins, HS Sekhon and SK Sain, 2009. Short duration of mungbean for the diversification of the rice-wheat system. Milestones in food legume research. The Peninsular Region. Kanpur. pp. 151-177.

Debnath, NC and V Hajra, 1972. Transformation of organic matter in soil in relation to mineralization of carbon and nutrient availability. India Soc. Soil Sci., 20: 95-102.

Efthimiadou A, D Bilalis, A Karkanis and B Froud-Williams, 2010. Combined organic/inorganic fertilization enhance soil quality and increased yield, photosynthesis and sustainability of sweet maize crop. Aust. J. Crop Sci., 4: 722-729.

Georgantas DA and HP Grigoropoulou, 2006. Phosphorus and organic matter removal from synthetic wastewater using Alum and Aluminum hydroxide. Global Nest J., 8: 121-130.

Gomez KA and AA Gomez, 1984. Statistical Procedure for Agricultural Research. 2nd Ed. Intl. Rice Res. Inst., Manila, Philippines. pp. 139-207.

Gholizadeh A, M Saberioon, L Boruvka, A Wayayok and MAM Soom, 2017. Leaf chlorophyll and nitrogen dynamics and their relationship to lowland rice yield for site-specific paddy management. Inf Process Agric., 4: 259-268.

Gilmour JT, A Mauromoustakos, PM Gale and RJ Norman, 1998. Kinetics of crop residue decomposition: variability among crops and years. Soil Sci. Soc. Amer. J., 62: 750-755.

Islam MS, 2006. Use of bioslurry as organic fertilizer in Bangladesh agriculture. Presentation at the International Workshop on the Use of Bioslurry Domestic Biogas Programmes, Bankok, Thiland.

Jenkinson, DS, RH Fox and JH Rayner, 1985. Interaction between fertilizer nitrogen and soil nitrogen - The socalled "Priming" effect. J. Soil Sci., 36: 425-444.

Khind CB, AS Josan and V Beri, 1983. Age of dhaincha, green matter and nitrogen economy in rice. Int. Rice Res. Newsl., 8: 17.

Kumar R, 2010. Studies on decomposing fungi of Sesbania aculeata L. in soil and its effects on soil borne plant pathogens. Ph.D. Thesis, Banaras Hindu University, Varanasi.

Kute SB and HS Mann, 1969. Effect of green manuring on the composition of soil and wheat crop and the balance of major plant nutrients in the soil after crop. Indian J. Agric. Sci., 39: 10-17.

Mann RA, MS Zia and M Saleem, 2000. An improved green manuring technology for sustaining the wheat rice system. Quarterly Sci. Vision., 6: 53.

Mondal U K, G Singh, G US Victor and KL Sharma, 2003. Green manuring: its effect on soil properties and crop growth under rice-wheat cropping system. European. J. Agron., 19: 225-237.

Odhiambo JJO, JBO Ogola and T Madzivhandila, 2010. Effect of green manure-maize rotation on maize grain yield and weed infestation levels. Afr. J. Agric. Res., 5: 618-625.

Paisancharoen K, N Viboonsuk, B Boonyong, C Wongwiwatchai, S Nakaviroj, C Suwan, P Sittibusaya, Kesawapitak and P Sonnas, 1990. Influence of green manures and chemical fertilizer on the yield of 3 cassava cultivars. In: Annual Reports of Soils and Fertilizers on Field Crops. Soil Science Division. Department of Agriculture, Thailand: 296-312.

Palaniappan SP, 1990. In: Proc. International Symposium on National Resources Management for Sustainable Agriculture, 6-10 February, 1990, New Delhi. p. 220. 
Pramanik MY, A Sarker, MAR Uddin and GM Fauk, 2009. Effect of phosphorous rate on growth, nodulation and biomass yield of green manure crops. J. Bangladesh Agril. Univ., 7: 23-28.

Rahman MH, MR Islam, M Jahiruddin, MY Rafii, MM Hanafi and MA Malek, 2013. Integrated nutrient management in maize-legume-rice cropping pattern and its impact on soil fertility. J. Food Agric. Environ., 11: 648-652.

Rinaudo G, B Dreyfus and Y Dommergues, 1983. Sesbania rostrata green manure and the nitrogen content of rice crop and soil. Soil Biol. Biochem., 15: 111-113.

Safiqual I, NK Paul, MD Alam, MR Uddin, UK Sarkar and MA Islam, 2015. Responses of Rice to Green Manure and Nitrogen Fertilizer Application. Online J. Bio. Sci., 15: 207-216.

Sahu BN and BC Nayak, 1971. Soil fertilizer investigation under continuous application of ammonium sulphate alone and in combination with the organic sources in Bhuhaneswar long-term fertility trials. In: Proc. Intl. Symp. Soil Fert. Eval., 1: 873-879.

Salahin N, KM Alam, MM Islam, L Nahar and MN Majid, 2013. Effect of green manure crops and tillage practice on maize and rice yields and soil properties. Aust. J. Crop Sci., 7: 1901-1911.

Sarwar AKMG, SMZ Hossain and SC Chanda, 2017. Effect of Dhaincha accessions on soil health and grain yield of rice. J. Bio. Agric. Res., 13: 1140-1145.

Singh NT, 1981. Green manure is a source of nutrients in rice production. Organic matter and rice. IRRI. Los Banos Philippine, pp. 217-288.

Srivastava N and K Girjesh, 2013. Biomass productivity of green manure crop Sesbania cannabina Poir (Dhaincha) in different planting density stress. Int. Res. J. Bio. Sci., 2: 48-53.

Swarup A 1987. Effect of pre-submergence and green manuring (Sesbania aculeata) on nutrition and yield of wetland rice (Oryza sativa L.) on a sodic soil. Biol. Fert. Soil, 5: 203-208.

Swain DK and SJ Sandip, 2010. Development of SPAD values of medium-and long-duration rice variety for site-specific nitrogen management. J Agron., 9: 38-44.

ZamanSK, NI Bhuiyan and MA Samad, 1995. Age of green manure crops: an important aspect of biomass production and nitrogen accumulation. Bangladesh J. Agric. Sci., 22: 107-112. 